\title{
Contribution of Remote Sensing on Crop Models: A Review
}

\author{
Dimitrios A. Kasampalis ${ }^{1}$ (1) , Thomas K. Alexandridis ${ }^{1, *}$ (i), Chetan Deva ${ }^{2}$, \\ Andrew Challinor ${ }^{2}{ }^{(\mathbb{D})}$, Dimitrios Moshou ${ }^{1}$ and Georgios Zalidis ${ }^{1}$ \\ 1 Department of Hydraulics, Soil Science and Agricultural Engineering, Faculty of Agriculture, \\ Aristotle University of Thessaloniki, 54124 Thessaloniki, Greece; dkasampa@agro.auth.gr (D.A.K.); \\ dmoshou@agro.auth.gr (D.M.); zalidis@agro.auth.gr (G.Z.) \\ 2 Institute for Climate and Atmospheric Science, School of Earth and Environment, The University of Leeds, \\ Leeds LS2 9JT, UK; eecd@leeds.ac.uk (C.D.); a.j.challinor@leeds.ac.uk (A.C.) \\ * Correspondence: thalex@agro.auth.gr; Tel.: +30-2310-991777
}

Received: 31 December 2017; Accepted: 20 March 2018; Published: 23 March 2018

check for updates

\begin{abstract}
Crop growth models simulate the relationship between plants and the environment to predict the expected yield for applications such as crop management and agronomic decision making, as well as to study the potential impacts of climate change on food security. A major limitation of crop growth models is the lack of spatial information on the actual conditions of each field or region. Remote sensing can provide the missing spatial information required by crop models for improved yield prediction. This paper reviews the most recent information about remote sensing data and their contribution to crop growth models. It reviews the main types, applications, limitations and advantages of remote sensing data and crop models. It examines the main methods by which remote sensing data and crop growth models can be combined. As the spatial resolution of most remote sensing data varies from sub-meter to $1 \mathrm{~km}$, the issue of selecting the appropriate scale is examined in conjunction with their temporal resolution. The expected future trends are discussed, considering the new and planned remote sensing platforms, emergent applications of crop models and their expected improvement to incorporate automatically the increasingly available remotely sensed products.
\end{abstract}

Keywords: crop models; earth observation; fusion; yield prediction; crop yield; vegetation indices; spatio-temporal scale

\section{Introduction and Historical Overview}

Crop growth models try to translate the relationship between plants and their environment, by simulating physiological processes in time frames, mostly daily, to estimate crop yield at harvesting. The knowledge of the expected yield is fundamental at various scales, as it determines various agronomical and socioeconomic decisions that could affect the livelihoods of a large percentage of the global population [1].

In the literature, crop models are sometimes also called crop yield models or agricultural system models. Despite how different scientists refer to crop models, all of them agree that a model is just a representation of the real world [2]. These models play an essential role in the development of sustainable land management for maximising sustainability goals to land managers and policymakers. Producers and decision makers in the rural sector require reliable information about the expected production volumes of crops [3]. In the 21st century, factors that influence crop growth and yield are well understood. At any given point in the field, the yield is the result of several factors or variables, genetics, plant population, crop management, climate, and the integration of stress that the crop faces during the growing season [4]. 
According to [5] a system is represented by a set mathematical equations, or in other words, these equations are used to model the processes of the system. Specifically, for a crop growth model, it simulates crop processes, up to the final step of the crop which is the harvested yield and contains quantitative information about the growth and the development of the crop.

Since the 1960s with the pioneering work of, C. T. de Wit of Wageningen University and the chemical engineer W. G. Duncan on crop growth models, a new age in agricultural science started to develop. De Wit's work [6], based on the theory that farming systems modelled by combining physical and biological principles set the foundations of agricultural modelling was the beginning of many studies in this new field of agricultural science. This model interpreted photosynthetic rates of crop canopies to estimate crop yield and was used by decision-makers as a crop management tool. This very early model was called Elementary Crop growth Simulator (ELCROS). The following years were characterised by the introduction of micrometeorology and quantification of canopy resistance to gas exchanges in crop models for improved simulation of transpiration, which resulted in the Basic Crop Growth Simulator (BACROS).

In the 1970s after the United States performed a large purchase of wheat from the Soviet Union, crop models received significant attention [7]. Thus, new research programs received funding to create crop models that take advantage of the capabilities of remote sensing data to predict the yield of major crops. One of the first attempts in this direction was the Large Area Crop Inventory Experiment (LACIE) that was funded by NASA and NOAA to develop a method for estimating wheat production worldwide by using LANDSAT data [8].

In the 1980s the International Benchmark Sites Network for Agrotechnology Transfer (IBSNAT) sponsored by the United States Department of Agriculture developed a model for tropical environments. The principal objective of this project was to understand how the system and its components function $[9,10]$. The need to make the models of IBSNAT more compatible regarding data inputs and applications resulted in the design of Decision Support System for Agrotechnology Transfer (DSSAT) [11].

These complex processes and interactions of plant, soil and atmosphere could be altered by climate change. According to Challinor et al. [12] the major challenge for future studies on the response of crops to climate change is the accuracy of the spatial information.

Remote sensing collects geographical information systematically for large areas at low cost, and thus has provided the means for natural and agricultural resources surveys during the last few decades. Remote sensing solves to some degree the uncertainty of spatial information on the crop parameters that are used for crop modelling. Several ways of incorporating remote sensing data with crop growth models have been proposed. In this paper, we attempt to review the most recent information about remote sensing data and their contribution to crop growth models.

\section{Crop Growth Models}

\subsection{Types of Crop Growth Models}

Crop growth models are roughly classified into different types, depending on the design of the model. Efforts to classify crop growth models have used the following categories:

Empirical models sometimes called correlative or statistical models. These models are expressed as regression equations (with one or a few parameters) and are based on direct descriptions of the observed data. They do not provide information about the mechanisms that give rise to response [13]. As a result, they are less data intensive than dynamic crop models. There are three main types of statistical models, time series, panel and cross-sectional approaches [14]. These models are particularly useful for identifying key relationships in historical data sets. Statistical models are often used to estimate crop yield in a particular environment in order to provide useful information to policymakers about management and production options [15]. Statistical models are not without limitations. They often cannot describe crop yield response in locations for which historical data sets are not available 
and environmental conditions differ from the location for which they were developed [16]. In addition, they may not be able to simulate the response of crop yield to future climates where other drivers are likely to change in ways that have not been observed in the past. For example, if management practices are adapted to cope with new climates in ways that have not been observed previously, statistical models will not be able to capture the integrated yield response of changes in both climate and production methods [16].

Dynamic models, sometimes called process-based models, simulate the progression of the crop through time using differential equations to describe crop development [13]. These equations are rooted in a process-based understanding of crop development. Within this conceptual umbrella, models employ functions which approximate the mechanistic plant and soil processes being simulated for a given time step [17]. These models include a larger number of input parameters and require more input data than empirical models [15]. Process-based models often require physiological data from field experiments to parameterise the model [17]. A major advantage of dynamic models vs. statistical models, is that they can be used by policy-makers to explore alternative futures under a range of future climates and management practices. They can also be used to estimate yield responses to changes in climate and management practices in regions where no previous simulations have been conducted [18].

Agricultural systems operate at several spatial and temporal scales. For example, they can be analysed at field, farm, regional or global scales [19] and over hours, days or whole seasons. Moving between scales requires scaling biophysical processes such as growth and yield as well as farm management practices [19] such as irrigation and fertilizer application. Dynamic process-based models can be classified by the scale of analysis for which they were designed. Broadly speaking, they fall into two main categories: field scale models, which aim to comprehensively simulate plant functions and less complex regional scale models, which often incorporate a mixture of canopy processes and broader scale crop-climate relationships [20]. ORYZA2000 is a good example of a field scale model [21], while the General Large Area Model (GLAM) is a good example of a regional scale model [22].

A list of common crop models is displayed in Table 1.

Table 1. List of the most common crop models.

\begin{tabular}{|c|c|c|}
\hline Crop Model & References & Website to Access the Model (dd/mm/yy) \\
\hline APSIM & [23] & APSIM Initiative. Available online: http://www.apsim.info (accessed on 21/03/2018) \\
\hline AgrometShell & [15] & $\begin{array}{l}\text { AgrometShell (AMS). Available online: http:/ / www.hoefsloot.com/agrometshell.htm } \\
\text { (accessed on 21/03/2018) }\end{array}$ \\
\hline Aquacrop & [24] & AquaCrop. Available online: http:/ / www.fao.org/aquacrop (accessed on 21/03/2018) \\
\hline CERES-wheat & [14] & $\begin{array}{l}\text { CERES Wheat 2.0. Available online: http:/ / nowlin.css.msu.edu/wheat_book/ (accessed } \\
\text { on 21/03/2018) }\end{array}$ \\
\hline CROPGRO-Soybean & [4] & $\begin{array}{l}\text { Ecobas. Available online: http://ecobas.org/www-server/rem/mdb/cropgro.html } \\
\text { (accessed on 21/03/2018) }\end{array}$ \\
\hline Cropsyst & [25] & $\begin{array}{l}\text { Washington State University, CropSyst. Available online: } \\
\text { http://modeling.bsyse.wsu.edu/CS_Suite_4/CropSyst/index.html (accessed on } \\
\text { 21/03/2018) }\end{array}$ \\
\hline DAISY & [26] & $\begin{array}{l}\text { International Soil Modeling Consortium i. Available online: } \\
\text { https:// soil-modeling.org/resources-links/model-portal/daisy (accessed on 21/03/2018) }\end{array}$ \\
\hline DSSAT & [9] & $\begin{array}{l}\text { Decision Support System for Agrotechnology Transfer. Available online: http:/ / dssat.net/ } \\
\text { (accessed on 21/03/2018) }\end{array}$ \\
\hline EPIC & [15] & $\begin{array}{l}\text { Texas A\&M AgriLife Research. Available online: https:/ / epicapex.tamu.edu/ (accessed } \\
\text { on 21/03/2018) }\end{array}$ \\
\hline FarmSim & [15] & $\begin{array}{l}\text { Wageningen-Models Library-FarmSim. Available online: } \\
\text { http://models.pps.wur.nl/node/961 (accessed on 21/03/2018) }\end{array}$ \\
\hline Fasset & [27] & $\begin{array}{l}\text { Farm ASSEssment Tool. Available online: http://www.fasset.dk/ (accessed on } \\
\text { 21/03/2018) }\end{array}$ \\
\hline GLAM & [22] & $\begin{array}{l}\text { Institute for Climate and Atmospheric Science (ICAS). Available online: } \\
\text { https:/ / www.see.leeds.ac.uk/research/icas/research-themes/climate-change-and- } \\
\text { impacts/climate-impacts/glam/ (accessed on 21/03/2018) }\end{array}$ \\
\hline
\end{tabular}


Table 1. Cont.

\begin{tabular}{ccl}
\hline Crop Model & References & \multicolumn{1}{c}{ Website to Access the Model (dd/mm/yy) } \\
\hline HERMES & {$[26]$} & $\begin{array}{l}\text { zalf. Available online: } \\
\text { http://www.zalf.de/de/forschung_lehre/software_downloads/Seiten/default.aspx } \\
\text { (accessed on 21/03/2018) }\end{array}$ \\
\hline ORYZAv3 & {$[21,28]$} & $\begin{array}{l}\text { International Rice Research Institute (IRRI). Available online: } \\
\text { https://sites.google.com/a/irri.org/oryza2000/about-oryza-version-3 (accessed on } \\
21 / 03 / 2018)\end{array}$ \\
\hline ROTASK & {$[29]$} & $\begin{array}{l}\text { INRA. Available online: http://www.inra.fr/en/Scientists-Students/Agricultural- } \\
\text { systems/All-reports/Modelling-and-agrosystems/STICS-an-agronomy-dynamo } \\
\text { (accessed on 21/03/2018) }\end{array}$ \\
\hline STICS & {$[30]$} & $\begin{array}{l}\text { Wageningen-Models Library-SUCROS. Available online: } \\
\text { http://models.pps.wur.nl/node/966 (accessed on 21/03/2018) }\end{array}$ \\
\hline SUCROS & {$[31]$} & $\begin{array}{l}\text { Soil Water Atmosphere Plant. Available online: http://www.swap.alterra.nl/ (accessed } \\
\text { on 21/03/2018) }\end{array}$ \\
\hline SWAP & {$[32]$} & $\begin{array}{l}\text { Wageningen-Models Library-WOFOST. Available online: } \\
\text { http://www.wageningenur.nl/en/Expertise-Services/Research-Institutes/alterra/ } \\
\text { Facilities-Products/Software-and-models/WOFOST.htm (accessed on 21/03/2018) }\end{array}$ \\
\hline WOFOST & {$[33]$} &
\end{tabular}

\subsection{Uses of Crop Growth Models}

Crop growth models have been used since the early 1960s, and the primary purpose of using them was to model processes at plant scale [2]. Crop growth models' applications can be classified into three main categories as (a) tools for decision making, (b) research tools, and (c) as tools for education and technology transfer [1].

Crop growth models can be used in crop management and decision making as a tool to determine optimum planting dates and evaluate weather risks. In addition, crop growth models can be used to predict crop performance where the crop has not been cultivated before [1]. Applications like this are critical in developing regions of the world. Crop growth models have been used to develop prescription maps for fertiliser applications [34].

Crop growth models analyse the relationships between physiological plant processes and the environment, mostly in a daily time step to estimate crop yield at harvest [35]. Crop models also have many applications as tools in research hypothesis testing; many scientists develop models to understand the various process of the crop-climate systems such as water flow and photosynthesis and to highlight areas where knowledge is missing [36].

Crop models may also be a valuable tool in assisting plant breeding efforts as they are able to incorporate the interactions between plant development, environment and genetic constraints [37]. The latter are introduced as model coefficients that can provide a mathematical bridge to understanding how particular parts of plant DNA (quantitative trait loci) can influence plant outcomes [37]. An important end goal of gene-phenotype modelling is to rank the performance of different genotypes in a wide range of environments of interest [38]. An advantage of using crop models in this pursuit over traditional empirical methods is the ability to test different representations of genotypes across the distribution of potential environmental conditions [38]. Messina et al. [39] demonstrated that crop modelling can be usefully employed in the breeding process through the creation of yield-trait performance landscapes. They also offered a tangible example of how this might work in practice using the Agricultural Production Systems sIMulator (APSIM) crop model in the breeding cycle for improvement of drought tolerant varieties of Maize in the US western corn belt.

Climate change is currently one of the significant threats to crop productivity. Crop growth models were used to study the potential impacts of climate change on crop growth and yield in various regions [22,40-42]. Early understanding of the effects that climate change has on crops may help farmers and decision makers to minimise the risks and increase food security. Additionally, as the effects of climate change increase, it is inevitable that in the same region some crops may have lower 
productivity. Crop models integrate different components and can be used as tools to understand genotype and environment interactions. These studies are essential to reduce the time required to test new varieties.

\subsection{Data Requirements}

Many crop growth models require a significant amount of input data which limits their usefulness for research. For example, WOFOST (WOrld FOod STudies) which was used by EU Joint Research Centre's Monitoring Agricultural Resources (MARS) Unit Mission, requires data for about 40 input parameters [43]. Food and Agriculture Organizaions (FAO) AquaCrop model requires a relatively smaller number of parameters and variables to run [44]. Every crop growth model requires information regarding crop management, soil, and weather, at least data for the temperature, phasic development, and growing degree days [45]. Input data may range in time scale between hourly, daily, or weekly time frames [46]. Hunt and Boote [47] defined for the first time a minimum amount of input data needed for operating crop growth models at a given location (Table 2).

Table 2. Minimum input data for crop growth models [47].

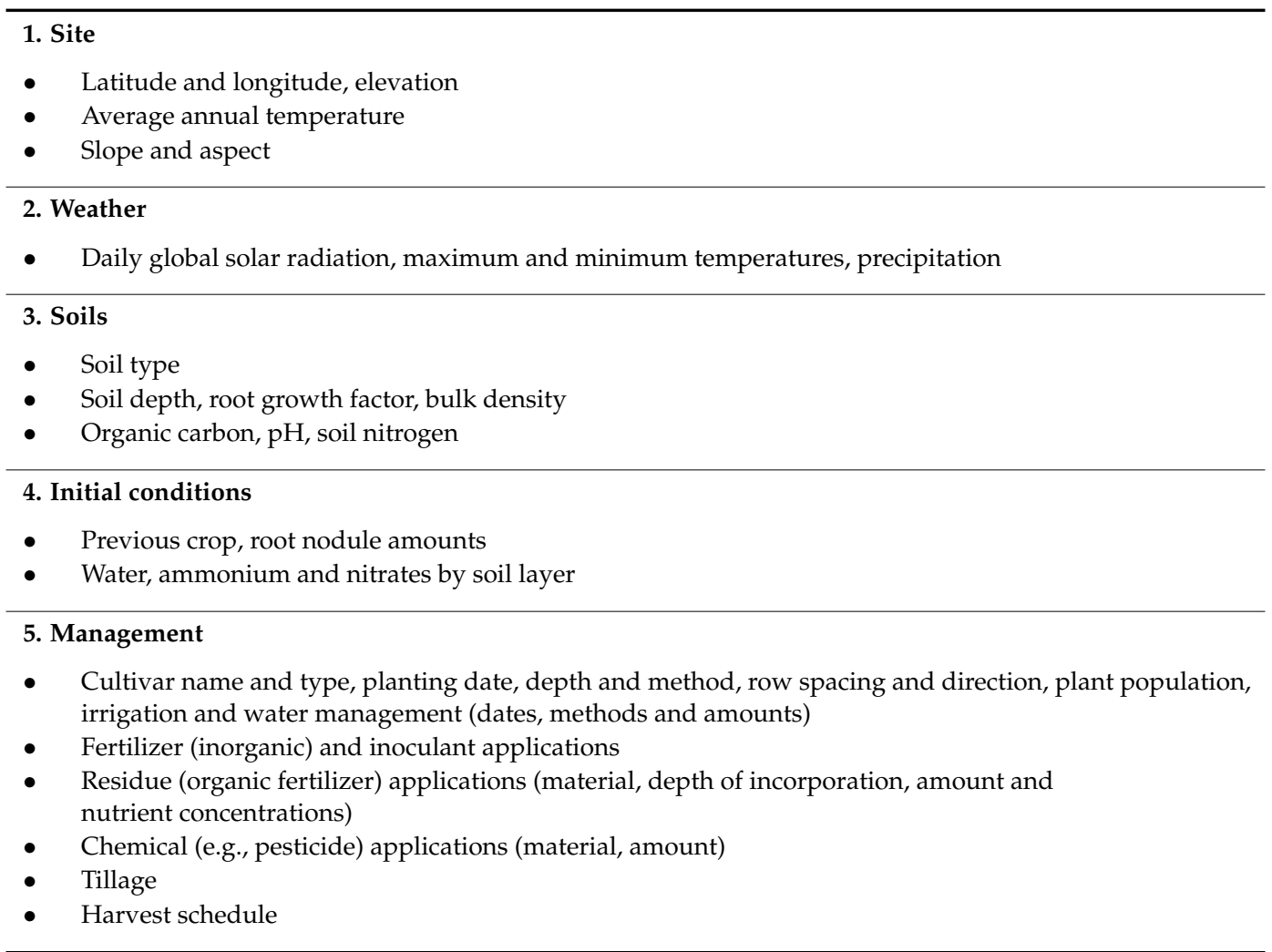

Published research should be transparent about how it was conducted, results and conclusions reached, and the data used. These data in most cases came from different sources and were used by different scientists, often through interdisciplinary collaboration [48]. During these collaborations, data interchange is inevitable, and due to the importance of the issues at stake to solve problems, make decisions and affect lives, it is ethical for scientists to allow others to examine and use their data [48].

Data standards are used to provide, promote and share any kind of data by enabling transparency and understanding of information sharing. Use of data standards is a means to achieve good data quality and transferability across research programs. One of the most extensive efforts to use data standards in agricultural science was the International Consortium for Agricultural Systems Applications (ICASA) and one of its predecessors the IBSNAT, which since 1983 started to develop data standards for documenting experiments. In their work White et al. [48] provide an overview of 
ICASA version 2.0 standards and describe in detail how the variables must be organised and provide emphasis on standardising vocabularies and clarifying relations among variables.

\subsection{Limitations and Advantages of Crop Models}

Crop modelling is a critical step towards developing and maintaining food security policies. However, models are merely tools used by policy-makers to answer questions that cannot be solved by addressing only regional or farm level problems. To address significant problems in agriculture, which is facing the significant challenge of feeding 9 bn people by 2050 it is necessary to take a cross-scale approach [49]. Boote, et al. [50] reviewed the potentials uses and limitations of crop growth models and suggested examining whether a model is appropriate to a particular purpose and whether the configuration of the model can be transferred to alternative environmental conditions. In their work Palosuo et al. [26] compared eight crop growth models for winter wheat, in order to examine how these crop models, perform at the field scale, the results showed that field-scale models could not be applied to larger-scale applications without proper parameterisation or ignoring essential factors about the model.

Model limitations are linked to the accuracy of the input data. Ideally, a model requires at least information about soil composition, weather and management practices, but often these data are not accessible. When this ideal state is not met, this causes uncertainties in the results [17,51]. Di Paola, et al. [15] also, argue that misleading model validation may be caused by comparing model results with the outputs of other more general models. As uncertainties in model results related to model calibration and inputs may be high, users of these models should always refer to the conditions in which said models were developed and tested [52].

Additionally, the lack of spatial information in crop growth models is a severe shortcoming, especially at regional scales [29]. On the other hand, crop growth models can provide essential information for economic impacts of different management activities and the weather [4].

To summarise, the main limitations of crop growth models are the cost of obtaining the necessary input data to run the model, the lack of spatial information in some cases, and the input data quality [53].

\section{Remote Sensing and Crop Growth Models}

\subsection{Estimation of Crop Parameters from Remote Sensing}

Remote sensing is the science and the art of acquiring information about an object by observing it from a distance [54]. Sensors can acquire data remotely while being on board different platforms, such as satellites, aeroplanes, UAVs or handheld devices [52].

Over the past few years, satellite images have been proved to be a useful tool for many agricultural applications. Healthy vegetation is very reflective in the near-infrared (NIR) but absorbs the red wavelengths. Thus, combinations of these two bands give a number of vegetation indices (VI) helpful to understand vegetation vigour [55]. VIs are mathematical equations or ratios of spectral bands and are designed to identify functional relationships between crops and other vegetation types [56,57]. An extensive review of the majority of VIs was conducted by Bannari et al. [58], and more recently by [59]. These indices have been created to minimise the effect of external factors in vegetation monitoring, to extract useful data for the canopy, such as leaf area index (LAI) and fraction of absorbed photosynthetically active radiation (fAPAR) [60]. LAI represents the surface area of leaves available for the exchange of energy between the plant and the atmosphere and is an important variable when used to model evapotranspiration, biomass production and yield [61]. fAPAR corresponds to the fraction of photosynthetically active radiation absorbed by the canopy and is essential for primary productivity models [62].

Remote sensing data provide timely, non-destructive, instantaneously and accurate estimations of the earth's surface over different areas. Since remote sensing techniques and data availability have 
improved over the last decade, this development has led to new advances in agricultural applications, such as yield prediction by processing biophysical quantities from remote sensing data, as well as high-throughput plant phenotyping with proximal sensors [63-65]. Yield forecasts used to be based on samples from farms, i.e., field work and written enquiries. Considering large-scale forecasts on regional, national or international scales, processing all these data is a costly and time-consuming task [31]. Hence the need for a fast, objective and standardised method to estimate yield, turned the attention of scientists to the possibilities of crop growth models and remote sensing.

The near parallel development of remote sensing and crop growth models has driven some scientists to recognise the usefulness of remote sensing in crop management, which lead to the development of combined applications [66]. Low-resolution remote sensing data have been broadly used in crop yield forecasting and monitoring. High temporal frequency combined with broad spatial coverage and low cost, has made these data a preferred choice for national and regional scale applications. Since the beginning, many scientists have used the available satellite data to retrieve canopy state variables over large areas. Among them, LAI is being monitored frequently across various scales and resolutions, and together with actual evapotranspiration and soil moisture estimations from thermal satellite images $[67,68]$, they have been used with crop models. Remote sensing data are mostly used to determine light interception (e.g., LAI or fAPAR), and provide the spatial information of the actual growth status of the crop. Most of the studies examine the assimilation of LAI as a variable for crop yield estimation but there are other factors affecting crop development, such as water stress, nutrient supply and pests [32]. Neiring et al. [69] assimilated remotely sensed LAI and soil moisture into DSSAT-CERES model and their results showed that in order to combine remote sensing data with crop models for estimating yield at single-season time scales, it will be necessary to modify our interpretation of crop development. They suggest the investigation of methods and other ancillary data for correlating leaf development with grain development directly. LAI and Evapotranspiration (ET) express two important crop processes, LAI simulates crop canopy development, which affect light interception and photosynthesis and ET reflects the available water to support crop growth. Improving the simulation of these variables is essential for accurate crop yield estimations [32]. Furthermore, these variables could be used to spatially calibrate the model by locally estimating the missing information in model parameters [70].

Hyperspectral remote sensing data, offer more spectral information and thus improved estimation of a wide range of plant biophysical properties [66]. Some studies have assimilated satellite hyperspectral data with crop models to estimate the potential yield or crop growth. For example, PROMET model (PROcess of Radiation Mass and Energy Transfer) was enhanced with CHRIS (Compact High Resolution Spectrometer) PROBA I satellite hyperspectral images to estimate spatial heterogeneity of winter wheat yield, in two fields in Germany [71]. The results showed an increase of accuracy of yield estimation by $20 \%$ which was attributed to the fields' spatial heterogeneity that was described with the hyperspectral satellite images. Mariotto et al. [72], compared hyperspectral data (Hyperion EO-1 satellite, field spectrometer) and multispectral reflectance data (Landsat, IRS, IKONOS, Quickbird) to estimate yield of various annual crops using empirical models. The results showed that hyperspectral models explained about $25 \%$ greater variability than multispectral models. At the plant level, proximal hyperspectral imaging and field spectroscopy has been used extensively to estimate plant biophysical properties and as phenotyping tool in agricultural research [73-75]. In an effort to assimilate these data to crop models, Li et al. [76] used two assimilation variables (LAI and canopy nitrogen accumulation, CNA) derived from a field spectrometer, in DSSAT-CERES crop model to improve yield prediction of winter wheat in an area in Beijing China. The results showed that both variables were accurately estimated with spectral indices and the integration of two state variables in the model was more robust than single variable integration.

The recent developments in technology resulted in the advanced use of Unmanned Aerial Vehicles (UAVs) in agriculture. The UAVs used in agriculture combined with lightweight and low-cost remote sensing sensors, are providing low-cost, timely and high spatial resolution data. But due to the small 
size of these devices and the limited battery capabilities, they are mostly used in precision farming applications to provide the within farm variability of factors influencing crop growth. Their operational use of small UAVs in regional scale is questioned [77], thus medium-altitude long-endurance (MALE) UAVs have been developed [78,79]. Several studies have examined the use of UAVs to obtain crop status, health and to provide effective support to crop management in general [80-82]. For example, Yao et al. [83] used UAVs to estimate LAI under varying growing conditions and different growing stages in order to provide technical support for nitrogen fertilization. In another study Vega et al. [84] examine the capability of the unmanned aerial vehicles to acquire multitemporal images during the growing season of sunflower in Spain at different temporal resolutions to estimate NDVI. The results of the study showed that linear regression between NDVI and grain yield were significant. Miniature hyperspectral sensors are becoming lighter and smaller and more suitable to be loaded on UAV platforms for earth observation applications in agriculture and forestry [82]. However, their usability is still limited due to high costs of associated with data acquisition and processing complexity.

In addition to raw satellite images, there are products available for a wide range of biophysical parameters that can be monitored operationally with remote sensing [85]. These products are generated regularly with automated algorithms based on image composites, which is a method for filling in gaps due to cloud cover. For instance, the available products for LAI include those from Terra MODIS that is composited every 8 days and has $1 \mathrm{~km}$ resolution, with an accuracy of $0.69\left(\mathrm{~m}^{2} / \mathrm{m}^{2}\right)$ [86], and the product GEOV01 derived from the SPOT-VEGETATION sensor, which is available every 10 days with $1 \mathrm{~km}$ spatial resolution worldwide with a reported RMSE of $0.5\left(\mathrm{~m}^{2} / \mathrm{m}^{2}\right)$ [87].

Vegetation indices are easily computed and thus widely used canopy state parameters. NDVI (Normalised Difference Vegetation Index) is one of the most commonly used since the 70 s. Numerous studies have used NDVI to analyse crop growth [88-90] and to estimate crop yield [88,91-94]. In the majority of these studies, the core strategy is to use linear regression models to predict the yield based on remotely sensed indices obtained during the growing season $[90,95]$, as well as to use VIs to calibrate the model by estimating input model parameters, such as LAI [70].

In some locations, optical sensors cannot be used, due to the persistent cloud coverage, or to the limits of their capabilities to provide information of the lower levels of canopy [96]. Synthetic Aperture Radar (SAR), has some advantages for monitoring crop status, when compared with optical sensors because these sensors are not affected by atmospheric conditions, can acquire data either day or night and of course due to fact that SAR sensors can penetrate crop canopies [96]. Additionally, Near-infrared reflectance is not sensitive to LAI and biomass of some crops such as winter wheat at medium to high canopy cover, and most of the vegetation indices demonstrate saturation phenomenon, nevertheless LAI and biomass at medium to high canopy cover could be estimated from remote sensing radar data which have stronger penetration capabilities [97,98]. Many studies have successfully demonstrated that SAR data can be used to monitor crop parameters. In a recent study conducted by Maki et al. [99] they used LAI derived from SAR images of COSMO-Sky-Med satellite and integrate it in a crop model (SIMRIW) to successfully estimate rice yield at regional scale.

\subsection{Linking Remote Sensing with Crop Growth Models}

Remote sensing can provide valuable information combined with crop growth models for yield assessment. In the 1970s Wiegand et al. [48] put forward that information derived from remote sensing data may increase the accuracy of crop modelling. There are three main methods through which remote sensing data is combined with crop models. The first is an indirect approach where remote sensing data is assimilated with a simulation model, either by calibrating the model or in a feedback loop used to adjust the model [100]. This method can provide canopy measurements as variables used by the crop growth model, as well as spatial and temporal information about these data. The other two methods are integrating remote sensing data in crop growth models by forcing or recalibration [101]. During forcing, model variables are replaced or adjusted using remote sensing data, while in recalibration model parameters or initial conditions are adjusted based on remote sensing data. An extensive recent 
review on data assimilation of remote sensing and crop models showing the potential to improve estimation accuracy of canopy variables, soil properties and yield have been conducted by Jin et al. [77].

Clevers et al. [29] used a semi-empirical approach (CLAIR model) for estimating LAI of a wheat field, in southern France using both ground-based and SPOT data. In this method, a weighted difference vegetation index (WDVI) was derived as a weighted difference between the measured NIR and red reflectance assuming that the ratio of NIR and red reflectance of bare soil is constant. Then, WDVI was used for estimating LAI. The results showed that remote sensing data proved to be a valuable tool for model run-time calibration, and thus improved regional estimates of crop yield, providing an essential tool for policymakers and trade.

Maas [100] described four alternative techniques for incorporating remote sensing data in crop growth models. Crop growth models consist of three parts, state variables, driving variables and parameters. The simplest way proposed, was to use remote sensing to evaluate one or more driving variables. Another way was to update a state variable of the model which was derived from remote sensing. The other ways were to re-initialise and/or re-calibrate the model, which were also called assimilation approaches, where remote sensing was used directly to re-calibrate the model.

Data assimilation fails to acknowledge errors observed on modelled values. Thus, a new assimilation strategy was developed to minimise the difference between observation and simulation by adapting either the vague model parameters, the initial conditions or the model state variables. Ensemble Kalman filter is a frequently used algorithm that relies on the assumption that the posterior density of every time step is a Gaussian distribution parameterised by a mean and a covariance [102].

\subsection{Scale Considerations}

Remote sensing data are available at scales from sub-meter to estimate within field variability for precision farming applications, to more than a kilometer for regional applications such as monitoring Africa for food security. Thus, the issue of identifying the appropriate scale for monitoring the phenomena under consideration has emerged [103,104], as well as issues of aggregating remotely sensed vegetation information to avoid insertion of errors [105].

Remote sensing satellites that offer a high spatial resolution (finer than $10 \mathrm{~m}$ ) usually have a low temporal resolution (repeat cycle) due to their narrow swath (coverage of a single image). Moreover, these satellites usually operate on demand, i.e., images are not acquired unless a customer or application orders them. SPOT, IKONOS and Quickbird are some high and very high-resolution satellites that fall into this category. On the contrary, low spatial resolution satellites (coarser than $300 \mathrm{~m}$ ) have wide enough swath to cover the globe in a single day. Terra MODIS, Sentinel-3 and NOAA AVHRR are examples of low resolution satellites. Data from low resolution satellites are preferred in crop modelling, as they can easily provide a time series of images to cover the crop growth season. A graphical overview of spectral, spatial, temporal and radiometric resolution of various optical satellite systems per application is presented in Figure 1.

The selection of the scale of the system being modelled depends on the questions being asked and who asks those questions [18]. For example, if the questions refer to the best management practices, how to make more profit from the land and how to protect the environment, the system to be modelled is at the field scale. Field-scale modelling assumes that the conditions in the field are similar and only soil may vary. Models run at field scale are also called point models. At farm and larger scales, the question that needs to be answered is how weather, soil, socioeconomic factors and crop management practices affect crops and how the answer to these questions can become a decision for policymakers. At this scale, models include biophysical responses, socioeconomic, environmental and business parameters. The same parameters are also used for models run at national or global scale. 


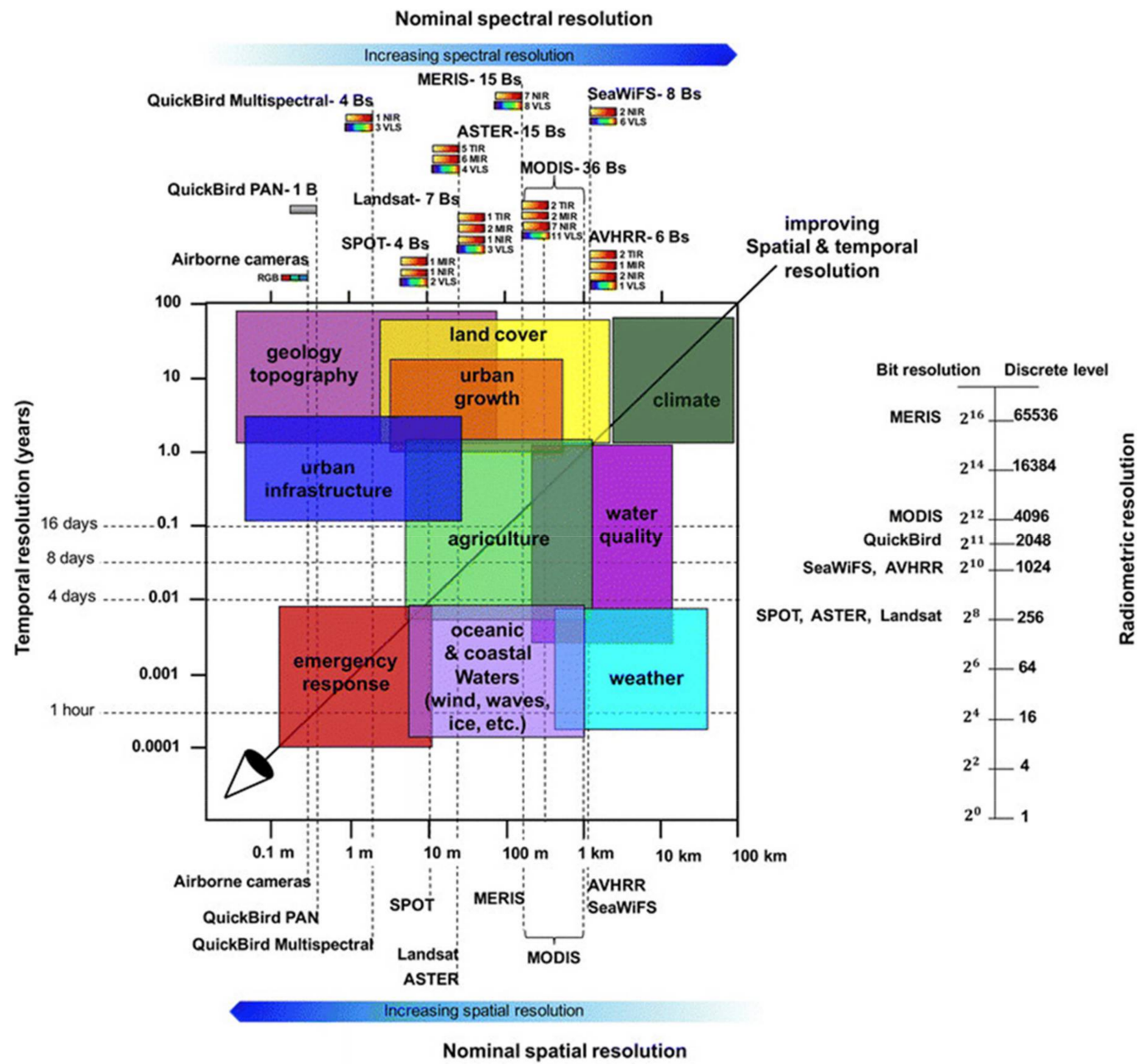

Figure 1. Relation of spatial, temporal and spectral resolution of satellite images [106].

At regional scale applications for monitoring crop growth and yield encounter some complications. One of them is the difficulty in obtaining data for crop parameters and management practices, it is also hard to validate modelling results, and additionally it can be difficult to simulate changes in crop yield forecasting caused by extreme weather conditions [102].

\subsection{Limitations and Advantages of Using Remote Sensing Data with Crop Models}

It should be clarified that crop models are not expected to provide spatial information per se; they might however use input spatial information to operate. Thus, a significant advantage provided by using remote sensing data with crop models is the addition of the spatial information, often absent from non-dimensional models $[29,70,107,108]$. Remote sensing data can provide spatial information, and as a result, it can be used for expanding their coverage in two-dimensional space [70]. This spatial information is very important for several applications including site-specific agriculture and food security that faces one of the most difficult challenges to monitor and provide reliable crop yield information, both temporally and spatially consistent [29,109]. Furthermore, monitoring crops and providing yield predictions at varying scales, before harvest time, is important for decision making in applications such as trading, logistics and insurance. 
Basso et al. [110] used remote sensing data assimilated with crop modelling to identify spatial patterns of crop growth variability in soybean. The results combining remote sensing data and the CROPGRO-Soybean model showed that it was able to identify management zones and to predict the yield across the field, providing a potential use in site specific agriculture. In the same context Guo et al. [111] used simulation zone partitioning using soil nutrient indices and remotely sensed spatial characteristics of wheat growth. The aim of their study was to accurately predict wheat growth parameters and yield spatially by partitioning a large area into smaller zones that have relatively similar crop growth characteristics and environment. The crop model was run on partitioning clusters, reducing the number of calculations required during the coupling of remote sensing data with a crop model.

In their work, Jin et al. [112] used FAOs' AquaCrop model and calibrated using spectral-based biomass values generated from fifteen spectral indices and particle swarm optimization (PSO). The primary goal of their work was to improve yield and biomass prediction of winter wheat yield in China, by assimilating field spectroscopic data into AquaCrop model with PSO algorithm. According to the writer, PSO is much easier to apply in and has high precision and rapid convergence. The results showed that the NDMI (Normalized difference matter index) is highly correlated with biomass because it does not contain red edge or short NIR data because these are profoundly influenced by chlorophyll content and canopy structure. Their results pointed out also that, AquaCrop model with PSO data assimilation algorithm could be used to simulate winter wheat biomass, by assimilating field spectroscopy data into the model, to improve winter wheat yield. The data assimilation method was used to minimise errors between the observed values from the field and the simulated values from AquaCrop model, and errors in the remote sensing data were reduced in data assimilation.

According to the literature, a reported disadvantage of using remote sensing data is the low spatial resolution of the satellites that offer ready-to-use products of high temporal resolution for easy operation with crop models [113]. They had proposed the use of higher resolution satellite data, such as from MODIS of PROBA-V.

Another advance of incorporating time series of remote sensing data in crop growth models is that the former provides quantification of the condition of the crop along the growing season [100]. Indeed, as crop models may often appear to fail when growing conditions deviate from optimum (e.g., due to biotic or abiotic stresses), frequent remote sensing data may provide the missing information of actual growing conditions [114]. However, as mentioned at the beginning, a model is only a representation of the real system and the quality of the results are linked heavily with the quality of the data used by the model.

\section{Future Trends and Challenges}

Climate change research is expected to drive the increased application of crop models. As the global circulation models produce future climate scenarios, the production of current agricultural systems is in question. The future of the current agricultural systems is being tested using crop growth models fed with projected meteorological data. Thus, an early warning could be issued for global food security to take appropriate mitigation and adaptation measures [12]. Among others, the newly launched project "AfriCultuReS-Enhancing Food Security in African Agricultural Systems with the Support of Remote Sensing" (European Union, Horizon 2020) is expected to benefit from this development.

Future integration of crop modelling and plant breeding is not without challenges. In particular, gene-phenotype modelling requires quantitative knowledge of genetic influences on physiological processes, which is not always available [35]. Further, the flow of information from genetically relevant parameters to physiological traits to production is not necessarily a straightforward one, since traits interact with each other to determine productivity [35]. Nevertheless, the potential to increase the scale of hybrid assessment both spatially and within the target population environment suggests that crop modelling will be an important addition to multi environment trials in future breeding cycles [115]. 
New and expected satellite launches promise higher quality data on vegetation. ESA's Sentinel-2a is a recently launched satellite that carries the Multispectral Imager (MSI) with spatial resolution of 10-60 m, designed amongst other things for monitoring vegetation parameters and together with Sentinel-2b satellite provide a temporal resolution of 5 days. This is expected to provide unprecedented usefulness for continuous coverage of high-resolution products at a temporal resolution which is more than adequate for monitoring vegetation conditions [104]. A future launch from European Space Agency (ESA) is FLEX (Fluorescence Explorer), which is expected to provide global coverage of photosynthetic activity of vegetation through monitoring chlorophyll fluorescence. The latter is considered a more accurate indicator of plant growth and stress than others used (LAI, fAPAR), but is harder to measure [116].

A recent trend in satellite remote sensing are the constellations of nanosatellites (mass $<10 \mathrm{~kg}$ ). These are designed as low-cost orbiting satellites with simple monitoring and communication instruments that can be launched in dozens, each following a consecutive orbit from the previous in order to provide frequent coverage at very high spatial resolution. Their low construction and launch cost promises easy replacement and long-term maintenance of the constellation. An operational example is the constellation of Planet Lab's 'Doves', which are designed to operate in tandem and cover the globe daily at 3-5 m spatial resolution [117]. A different trend is the development of High Altitude Pseudo Satellites (HAPS) for applications in environmental monitoring and other non-defence uses. HAPS are remotely operated aircrafts positioned above $20 \mathrm{~km}$ altitude in the stratosphere, for very long duration flights and have the potential to stay over a fixed point on Earth from weeks to months. However, it yet to be proven that these systems could provide an operational and cost-effective source of information, considering the temporal requirements of crop models to cover at least a cropping season.

Coordinating crop model improvement and projection across spatial scales is a major challenge for crop modelling [118]. At global scales, the trend towards inclusion of crop models within integrated assessment models [119], and the increasing ability to run multi-model gridded studies [120], are resulting in an increased capacity for prediction. However, assimilation of data at global scales is difficult, which makes regional-scale risk assessments [121] an easier target for incorporation of satellite data. In this context, the increasing use of "big data" and smart sensors for agriculture [121] provides an opportunity for multiple sources of information, including remotely sensed data, to be combined into one predictive system.

Linking across spatial scales is not the only challenge facing greater integration of crop models and remotely sensed data. Agriculture globally is now being conducted in changing climates and with ongoing, often autonomous, adaptations occurring [122]. Remote sensing may have a role in tracking these changes, as well as the land use changes that they imply. These land use changes are the result of a complex set of drivers, including, inter alia, climate policy [123] and food demand [124]. Land use changes can also have implications for the skill of crop models [125].

The combination of crop models with data derived from UAVs is recently gaining more attention. With the expanding technology of UAVs and newly and more sophisticated light sensors being available on the market the assimilation of UAV remote sensing data and crop models for field scale applications is expected to boom [82]. For example, Bendig et al. [126] combined Vis derived from $\mathrm{UAV}$, and ground based hyperspectral data and plant height information to estimate biomass in barley. Another example is the work from Zhou et al. [127] where multispectral images and digital images acquired at critical growth stages and used to correlate with grain yield and LAI to identify the appropriate period and optimal Vis for rice yield prediction and to assess the possibility of multi-temporal VIs for yield prediction by using UAV images. The results showed that multispectral and digital images are both reliable for rice yield and growth prediction.

Satellite hyperspectral data have been mainly used for research, thus their availability, spatial coverage, and timeliness of delivery hinders their use in operational applications with crop growth models. A boom is expected in the field of hyperspectral UAV, which may provide the solution that is 
needed for operational integration of hyperspectral data with crop models. This may be achieved due to the technological advances in miniature hyperspectral imaging cameras that capture high quality data from low cost UAV systems, and the development of faster artificial intelligence algorithms which allow near real-time processing of "big data".

\section{Conclusions}

Crop models and remote sensing have had parallel development courses. This paper describes the background and the efforts of linking the two for improved crop modelling. It also examines the main methods of combining remote sensing data and crop models, and includes issues of scale, the effect of climate change and applications in early warning systems for food security and crop breeding. It discusses the future trends, considering planned remote sensing satellite missions, alternative sources of remote sensing data and the expected improvements of crop models.

The main advantages from incorporating remote sensing data into crop models are the representation of the missing spatial information of the latter and the more accurate description of the crop's actual condition along various stages of the growing season. The reported disadvantages refer to the accuracy of remotely sensed information and the potential appearance of clouds that obstruct satellite data acquisition.

Crop models are expected to adapt to facilitate climate change research as well as the requirements of gene-phenotype modelling. They should benefit from the future trends of remote sensing, including new platforms (UAVs, nanosatellites and planned satellite missions) and more sensitive imaging sensors (e.g., hyperspectral).

Considering the advantages and the wide applicability of the combination of the two, it is certain that the collaboration of remote sensing data with crop models will increase, hopefully by incorporating automated procedures that will improve their performance. The so-called big data revolution is the context in which this collaboration will doubtless unfold. Techniques for data assimilation and quality checking will need to be at the heart of this promising avenue of research if it is to deliver reliable and skillful predictions.

Acknowledgments: This work was supported by the European Union's Horizon 2020 research and innovation programme under grant agreement No. 774652 "AfriCultuReS-Enhancing Food Security in African Agricultural Systems with the Support of Remote Sensing".

Author Contributions: D.A.K., T.K.A. and A.C. conceived and designed the work; D.A.K. and C.D. analyzed the literature; D.A.K., T.K.A., C.D. and A.C. wrote the paper; D.M. and G.Z. reviewed and corrected the paper.

Conflicts of Interest: The authors declare no conflict of interest.

\section{References}

1. Murthy, V.R.K. Crop Growth Modeling and Its Applications in Agricultural Meteorology. In Proceedings of the Satellite Remote Sensing and GIS Applications in Agricultural Meteorology, Dehra Dun, India, 7-11 July 2003; World Meteorological Organisation: Dehra Dun, India, 2003; pp. 235-261.

2. Van Ittersum, M.K.; Donatelli, M. Modelling cropping systems-Highlights of the symposium and preface to the special issues. Eur. J. Agron. 2003, 18, 187-197. [CrossRef]

3. Soria-Ruiz, J.; Fernandes-Ordonez, Y.; Quijano-Carranza, A.; Macías-Cervantes, J.; Sauceda, P.; Gonzalez, D.; Quintana, J. Remote Sensing and Simulation Model for Crop Management. In Proceedings of the PIERS Proceedings, Kuala Lumpur, Malaysia, 27-30 March 2012; pp. 1134-1137.

4. Batchelor, W.D.; Basso, B.; Paz, J.O. Examples of strategies to analyze spatial and temporal yield variability using crop models. Eur. J. Agron. 2002, 18, 141-158. [CrossRef]

5. Oteng-Darko, P.; Yeboah, S.; Addy, S.N.T.; Amponsah, S.; Danquah, E.O. Crop modeling: A tool for agricultural research-A review. E3 J. Agric. Res. Dev. 2012, 2, 001-006.

6. De Wit, C.T. Photosynthesis of Leaf Canopies; PUDOC: Wageningen, The Netherlands, 1965. 
7. Pinter, P.J.J.; Hatfield, J.L.L.; Schepers, J.S.S.; Barnes, E.M.; Moran, M.S.; Daughtry, C.S.T.; Upchurch, D.R.; Pinter, P.J., Jr.; Hatfield, J.L.; Schepers, J.S. Remote sensing for crop management. Photogramm. Eng. Remote Sen. 2003, 69, 647-664. [CrossRef]

8. Erickson, J.D. The lacie experiment in satellite aided monitoring of global crop production. In The Role of Terrestrial Vegetation in the Global Carbon Cycle: Measurement by Remote Sensing; John Wiley \& Sons: New York, NY, USA, 1984; pp. 191-217.

9. Jones, J.W.; Hoogenboom, G.; Porter, C.H.; Boote, K.J.; Batchelor, W.D.; Hunt, L.A.; Wilkens, P.W.; Singh, U.; Gijsman, A.J.; Ritchie, J.T.; et al. The dssat cropping system model. Eur. J. Agron. 2003, 18, 235-265. [CrossRef]

10. Roubtsova, E. Modelling and Simulation of Diffusive Processes Methods and Applications; Springer: London, UK, 2014.

11. Johnson, L.F.; Roczen, D.E.; Youkhana, S.K.; Nemani, R.R.; Bosch, D.F. Mapping vineyard leaf area with multispectral satellite imagery. Comput. Electron. Agric. 2003, 38, 33-44. [CrossRef]

12. Challinor, A.J.; Ewert, F.; Arnold, S.; Simelton, E.; Fraser, E. Crops and climate change: Progress, trends, and challenges in simulating impacts and informing adaptation. J. Exp. Bot. 2009, 60, 2775-2789. [CrossRef] [PubMed]

13. Rauff, K.O.; Bello, R. A review of crop growth simulation models as tools for agricultural meteorology. Agric. Sci. 2015, 6, 8. [CrossRef]

14. Lobell, D.B.; Burke, M.B. On the use of statistical models to predict crop yield responses to climate change. Agric. For. Meteorol. 2010, 150, 1443-1452. [CrossRef]

15. Di Paola, A.; Valentini, R.; Santini, M. An overview of available crop growth and yield models for studies and assessments in agriculture. J. Sci. Food Agric. 2016, 96, 709-714. [CrossRef] [PubMed]

16. Jones, J.W.; Antle, J.M.; Basso, B.; Boote, K.J.; Conant, R.T.; Foster, I.; Godfray, H.C.J.; Herrero, M.; Howitt, R.E.; Janssen, S.; et al. Brief history of agricultural systems modeling. Agric. Syst. 2017, 155, 240-254. [CrossRef] [PubMed]

17. Wallach, D.; Makowski, D.; Jones, J.W.; Brun, F.; Jones, J.W. Working with Dynamic Crop Models; Academic Press: Cambridge, MA, USA, 2014; pp. 407-436.

18. Jones, J.W.; Antle, J.M.; Basso, B.; Boote, K.J.; Conant, R.T.; Foster, I.; Godfray, H.C.J.; Herrero, M.; Howitt, R.E.; Janssen, S.; et al. Toward a new generation of agricultural system data, models, and knowledge products: State of agricultural systems science. Agric. Syst. 2017, 155, 269-288. [CrossRef] [PubMed]

19. Ewert, F.; van Ittersum, M.K.; Heckelei, T.; Therond, O.; Bezlepkina, I.; Andersen, E. Scale changes and model linking methods for integrated assessment of agri-environmental systems. Agric. Ecosyst. Environ. 2011, 142, 6-17. [CrossRef]

20. Ramirez-Villegas, J.; Watson, J.; Challinor, A.J. Identifying traits for genotypic adaptation using crop models. J. Exp. Bot. 2015, 66, 3451-3462. [CrossRef] [PubMed]

21. Li, T.; Angeles, O.; Marcaida, M.; Manalo, E.; Manalili, M.P.; Radanielson, A.; Mohanty, S. From oryza2000 to oryza (v3): An improved simulation model for rice in drought and nitrogen-deficient environments. Agric. For. Meteorol. 2017, 237-238, 246-256. [CrossRef] [PubMed]

22. Challinor, A.J.; Wheeler, T.R.; Craufurd, P.Q.; Slingo, J.M.; Grimes, D.I.F. Design and optimisation of a large-area process-based model for annual crops. Agric. For. Meteorol. 2004, 124, 99-120. [CrossRef]

23. McCown, R.L.; Hammer, G.L.; Hargreaves, J.N.G.; Holzworth, D.P.; Freebairn, D.M. Apsim: A novel software system for model development, model testing and simulation in agricultural systems research. Agric. Syst. 1996, 50, 255-271. [CrossRef]

24. Steduto, P.; Hsiao, T.C.; Raes, D.; Fereres, E. Aquacrop-The fao crop model to simulate yield response to water. Agron. J. 2009, 101, 426-437. [CrossRef]

25. Stöckle, C.O.; Donatelli, M.; Nelson, R. Cropsyst, a cropping systems simulation model. Eur. J. Agron. 2003, 18, 289-307. [CrossRef]

26. Palosuo, T.; Kersebaum, K.C.; Angulo, C.; Hlavinka, P.; Moriondo, M.; Olesen, J.E.; Patil, R.H.; Ruget, F.; Rumbaur, C.; Takáč, J.; et al. Simulation of winter wheat yield and its variability in different climates of europe: A comparison of eight crop growth models. Eur. J. Agron. 2011, 35, 103-114. [CrossRef]

27. Olesen, J.E.; Hansen, P.K.; Berntsen, J.; Christensen, S. Simulation of above-ground suppression of competing species and competition tolerance in winter wheat varieties. Field Crops Res. 2004, 89, 263-280. [CrossRef]

28. Bouman, B.A.M.; van Laar, H.H. Description and evaluation of the rice growth model oryza2000 under nitrogen-limited conditions. Agric. Syst. 2006, 87, 249-273. [CrossRef] 
29. Clevers, J.G.P.W.; Vonder, O.W.; Jongschaap, R.E.E.; Desprats, J.-F.; King, C.; Prévot, L.; Bruguier, N. Using spot data for calibrating a wheat growth model under mediterranean conditions. Agronomie 2002, 22, 687-694. [CrossRef]

30. Brisson, N.; Mary, B.; Ripoche, D.; Jeuffroy, M.H.; Ruget, F.; Nicoullaud, B.; Gate, P.; Devienne-Barret, F.; Antonioletti, R.; Durr, C.; et al. Stics: A generic model for the simulation of crops and their water and nitrogen balances. I. Theory and parameterization applied to wheat and corn. Agronomie 1998, 18, 311-346. [CrossRef]

31. Bouman, B.A.M. Linking physical remote sensing models with crop growth simulation models, applied for sugar beet. Int. J. Remote Sens. 1992, 13, 2565-2581. [CrossRef]

32. Huang, J.; Ma, H.; Su, W.; Zhang, X.; Huang, Y.; Fan, J.; Wu, W. Jointly assimilating MODIS LAI and et products into the SWAP model for winter wheat yield estimation. IEEE J. Sel. Top. Appl. Earth Observ. Remote Sens. 2015, 8, 4060-4071. [CrossRef]

33. Van Diepen, C.A.; Wolf, J.; van Keulen, H.; Rappoldt, C. Wofost: A simulation model of crop production. Soil Use Manag. 1989, 5, 16-24. [CrossRef]

34. Werner, A.; Dölling, S.; Jarfe, A.; Kühn, J.; Pauly, J.; Roth, R. Deriving Maps of Yield-Potentials with Crop Models, Site Information and Remote Sensing; American Society of Agronomy: Madison, WI, USA, 2000; pp. 1-20.

35. Asseng, S.; Ewert, F.; Rosenzweig, C.; Jones, J.W.; Hatfield, J.L.; Ruane, A.C.; Boote, K.J.; Thorburn, P.J.; Rötter, R.P.; Cammarano, D.; et al. Uncertainty in simulating wheat yields under climate change. Nat. Clim. Chang. 2013, 3, 827-832. [CrossRef]

36. Jame, Y.W.; Cutforth, H.W. Crop growth models for decision support systems. Can. J. Plant Sci. 1996, 76, 9-19. [CrossRef]

37. Yin, X.Y.; Struik, P.C.; Kropff, M.J. Role of crop physiology in predicting gene-to-phenotype relationships. Trends Plant Sci. 2004, 9, 426-432. [CrossRef] [PubMed]

38. Parent, B.; Tardieu, F. Can current crop models be used in the phenotyping era for predicting the genetic variability of yield of plants subjected to drought or high temperature? J. Exp. Bot. 2014, 65, 6179-6189. [CrossRef] [PubMed]

39. Messina, C.D.; Podlich, D.; Dong, Z.S.; Samples, M.; Cooper, M. Yield-trait performance landscapes: From theory to application in breeding maize for drought tolerance. J. Exp. Bot. 2011, 62, 855-868. [CrossRef] [PubMed]

40. Lobell, D.B.; Field, C.B.; Cahill, K.N.; Bonfils, C. Impacts of future climate change on california perennial crop yields: Model projections with climate and crop uncertainties. Agric. For. Meteorol. 2006, 141, $208-218$. [CrossRef]

41. Watson, J.; Challinor, A.J.; Fricker, T.E.; Ferro, C.A.T. Comparing the effects of calibration and climate errors on a statistical crop model and a process-based crop model. Clim. Chang 2015, 132, 93-109. [CrossRef]

42. Challinor, A.J.; Wheeler, T.R.; Slingo, J.M.; Hemming, D. Quantification of physical and biological uncertainty in the simulation of the yield of a tropical crop using present-day and doubled $\mathrm{CO}_{2}$ climates. Philos. Trans. R. Soc. B Biol. Sci. 2005, 360, 2085-2094. [CrossRef] [PubMed]

43. Khan, M.R. Crops from Space: Improved Earth Observation Capacity to Map Crop Areas and to Quantify Production; University of Twente: Enschede, The Netherlands, 2011.

44. Mkhabela, M.S.; Bullock, P.R. Performance of the fao aquacrop model for wheat grain yield and soil moisture simulation in western Canada. Agric. Water Manag. 2012, 110, 16-24. [CrossRef]

45. Monteith, J.L.; Moss, C.J. Climate and the efficiency of crop production in britain [and discussion]. Philos. Trans. R. Soc. Lond. Series B Biol. Sci. 1977, 281, 277-294. [CrossRef]

46. Nix, H.A. Minimum Data Sets for Agrotechnology Transfer. In Proceedings of the International Symposium on Minimum Data Sets for Agrotechnology Transfer, ICRISAT Center, Patancheru, India, 21-26 March 1983; ICRISAT Center: Patancheru, India, 1983; pp. 181-188.

47. Hunt, L.A.; Boote, K.J. Data for model operation, calibration, and evaluation. In Understanding Options for Agricultural Production; Tsuji, G.Y., Hoogenboom, G., Thornton, P.K., Eds.; Springer: Dordrecht, The Netherlands, 1998; pp. 9-39.

48. White, J.W.; Hunt, L.A.; Boote, K.J.; Jones, J.W.; Koo, J.; Kim, S.; Porter, C.H.; Wilkens, P.W.; Hoogenboom, G. Integrated description of agricultural field experiments and production: The ICASA version 2.0 data standards. Comput. Electron. Agric. 2013, 96, 1-12. [CrossRef] 
49. Dalgaard, T.; Hutchings, N.J.; Porter, J.R. Agroecology, scaling and interdisciplinarity. Agric. Ecosyst. Environ. 2003, 100, 39-51. [CrossRef]

50. Boote, K.J.; Jones, J.W.; Pickering, N.B. Potential uses and limitations of crop models. Agron. J. 1996, 88, 704-716. [CrossRef]

51. Ahuja, L.R.; Ma, L. Parameterization of agricultural system models: Current approaches and future needs. In Agricultural System Models in Field Research and Technology Transfer; Lewis Publishers: Boca Raton, FL, USA, 2002.

52. Bregaglio, S.; Frasso, N.; Pagani, V.; Stella, T.; Francone, C.; Cappelli, G.; Acutis, M.; Balaghi, R.; Ouabbou, H.; Paleari, L.; et al. New multi-model approach gives good estimations of wheat yield under semi-arid climate in Morocco. Agron. Sustain. Dev. 2015, 35, 157-167. [CrossRef]

53. Bhatia, A.K. Modelling and Simulation of Diffusive Processes: Methods and Applications; Basu, S.K., Kumar, N., Eds.; Springer International Publishing: Cham, The Netherlands, 2014; pp. 315-332.

54. Fischer, W.A.; Hemphill, W.R.; Kover, A. Progress in remote sensing (1972-1976). Photogrammetria 1976, 32, 33-72. [CrossRef]

55. Campbell, J.B. Introduction to Remote Sensing; The Guilford Press: New York, NY, USA, 1987.

56. Campbell, J.B.; Wynne, R.H. Introduction to Remote Sensing, 5th ed.; Guilford Press: New York, NY, USA, 2011.

57. Wiegand, C.L.; Richardson, A.J.; Kanemasu, E.T. Leaf area index estimates for wheat from landsat and their implications for evapotranspiration and crop modeling. Agron. J. 1979, 71, 336-342. [CrossRef]

58. Bannari, A.; Morin, D.; Bonn, F.; Huete, A.R. A review of vegetation indices. Remote Sens. Rev. 1995, 13, 95-120. [CrossRef]

59. Silleos, N.G.; Alexandridis, T.K.; Gitas, I.Z.; Perakis, K. Vegetation indices: Advances made in biomass estimation and vegetation monitoring in the last 30 years. Geocarto Int. 2006, 21, 21-28. [CrossRef]

60. Baret, F.; Guyot, G. Potentials and limits of vegetation indices for LAI and APAR assessment. Remote Sens. Environ. 1991, 35, 161-173. [CrossRef]

61. Broge, N.H.; Leblanc, E. Comparing prediction power and stability of broadband and hyperspectral vegetation indices for estimation of green leaf area index and canopy chlorophyll density. Remote Sens. Environ. 2001, 76, 156-172. [CrossRef]

62. Baret, F.; Bacour, C.; Béal, D.; Weiss, M.; Berthelot, B.; Regner, P. Algorithm Theoretical Basis Document for MERIS Top of Canopy Land Products (toc_veg); INRA \& Noveltis: Avignon, France, 2006; pp. 1-25.

63. Clevers, J.; Buler, C.; Vanleeuwen, H.; Bouman, B. A framework for monitoring crop growth by combining directional and spectral remote sensing information. Remote Sens. Environ. 1994, 50, 161-170. [CrossRef]

64. Dadhwal, V. Crop Growth and Productivity Monitoring and Simulation Using Remote Sensing and Gis. In Proceedings of the Remote Sensing and GIS Applications in Agricultural Meteorology, Dehra Dun, India, 7-13 July 2003; Indian Institute of Remote Sensing: Dehra Dun, India, 2003; pp. 263-289.

65. Li, L.; Zhang, Q.; Huang, D.F. A review of imaging techniques for plant phenotyping. Sensors 2014, 14, 20078-20111. [CrossRef] [PubMed]

66. Dorigo, W.A.; Zurita-Milla, R.; de Wit, A.J.W.; Brazile, J.; Singh, R.; Schaepman, M.E. A review on reflective remote sensing and data assimilation techniques for enhanced agroecosystem modeling. Int. J. Appl. Earth Observ. Geoinf. 2007, 9, 165-193. [CrossRef]

67. Cherif, I.; Alexandridis, T.K.; Jauch, E.; Chambel-Leitao, P.; Almeida, C. Improving remotely sensed actual evapotranspiration estimation with raster meteorological data. Int. J. Remote Sens. 2015, 36, 4606-4620. [CrossRef]

68. Alexandridis, T.K.; Cherif, I.; Bilas, G.; Almeida, W.G.; Hartanto, I.M.; van Andel, S.J.; Araujo, A. Spatial and temporal distribution of soil moisture at the catchment scale using remotely-sensed energy fluxes. Water 2016, 8, 32. [CrossRef]

69. Nearing, G.S.; Crow, W.T.; Thorp, K.R.; Moran, M.S.; Reichle, R.H.; Gupta, H.V. Assimilating remote sensing observations of leaf area index and soil moisture for wheat yield estimates: An observing system simulation experiment. Water Resour. Res. 2012, 48. [CrossRef]

70. Launay, M.; Guerif, M. Assimilating remote sensing data into a crop model to improve predictive performance for spatial applications. Agric. Ecosyst. Environ. 2005, 111, 321-339. [CrossRef]

71. Oppelt, N.M. Use of remote sensing data to assist crop modeling. J. Appl. Remote Sens. 2010, 4, 041896. [CrossRef] 
72. Mariotto, I.; Thenkabail, P.S.; Huete, A.; Slonecker, E.T.; Platonov, A. Hyperspectral versus multispectral crop-productivity modeling and type discrimination for the hyspiri mission. Remote Sens. Environ. 2013, 139, 291-305. [CrossRef]

73. Yendrek, C.R.; Tomaz, T.; Montes, C.M.; Cao, Y.; Morse, A.M.; Brown, P.J.; McIntyre, L.M.; Leakey, A.D.B.; Ainsworth, E.A. High-throughput phenotyping of maize leaf physiological and biochemical traits using hyperspectral reflectance. Plant Physiol. 2017, 173, 614-626. [CrossRef] [PubMed]

74. Frels, K.; Guttieri, M.; Joyce, B.; Leavitt, B.; Baenziger, P.S. Evaluating canopy spectral reflectance vegetation indices to estimate nitrogen use traits in hard winter wheat. Field Crops Res. 2018, 217, 82-92. [CrossRef]

75. Ge, Y.; Bai, G.; Stoerger, V.; Schnable, J.C. Temporal dynamics of maize plant growth, water use, and leaf water content using automated high throughput $\mathrm{rgb}$ and hyperspectral imaging. Comput. Electron. Agric. 2016, 127, 625-632. [CrossRef]

76. Li, Z.; Wang, J.; Xu, X.; Zhao, C.; Jin, X.; Yang, G.; Feng, H. Assimilation of two variables derived from hyperspectral data into the dssat-ceres model for grain yield and quality estimation. Remote Sens. 2015, 7, 12400-12418. [CrossRef]

77. Jin, X.; Kumar, L.; Li, Z.; Feng, H.; Xu, X.; Yang, G.; Wang, J. A review of data assimilation of remote sensing and crop models. Eur. J. Agron. 2018, 92, 141-152. [CrossRef]

78. Panagiotou, P.; Kaparos, P.; Salpingidou, C.; Yakinthos, K. Aerodynamic design of a male UAV. Aerosp. Sci. Technol. 2016, 50, 127-138. [CrossRef]

79. Goetzendorf-Grabowski, T.; Frydrychewicz, A.; Goraj, Z.; Suchodolski, S. Male UAV desian of an increased reliability level. Aircr. Eng. Aerosp. Technol. 2006, 78, 226-235. [CrossRef]

80. Jannoura, R.; Brinkmann, K.; Uteau, D.; Bruns, C.; Joergensen, R.G. Monitoring of crop biomass using true colour aerial photographs taken from a remote controlled hexacopter. Biosyst. Eng. 2015, 129, 341-351. [CrossRef]

81. Rasmussen, J.; Ntakos, G.; Nielsen, J.; Svensgaard, J.; Poulsen, R.N.; Christensen, S. Are vegetation indices derived from consumer-grade cameras mounted on UAVs sufficiently reliable for assessing experimental plots? Eur. J. Agron. 2016, 74, 75-92. [CrossRef]

82. Adao, T.; Hruska, J.; Padua, L.; Bessa, J.; Peres, E.; Morais, R.; Sousa, J.J. Hyperspectral imaging: A review on UAV-based sensors, data processing and applications for agriculture and forestry. Remote Sens. 2017, 9, 1110. [CrossRef]

83. Yao, X.; Wang, N.; Liu, Y.; Cheng, T.; Tian, Y.; Chen, Q.; Zhu, Y. Estimation of wheat LAI at middle to high levels using unmanned aerial vehicle narrowband multispectral imagery. Remote Sens. 2017, 9, 1304. [CrossRef]

84. Vega, F.A.; Ramírez, F.C.; Saiz, M.P.; Rosúa, F.O. Multi-temporal imaging using an unmanned aerial vehicle for monitoring a sunflower crop. Biosyst. Eng. 2015, 132, 19-27. [CrossRef]

85. Silleos, N.; Strati, S.; Cherif, I.; Topaloglou, C.; Alexandridis, T.K.; Iordanidis, C.; Stavridou, D.; Monachou, S.; Kalogeropoulos, C.; Bilas, G.; et al. Weekly time series of LAI maps at river basin scale using MODIS satellite data. In Proceedings of the 1st International GEOMAPPLICA Conference, Skiathos Island, Greece, 8-10 September 2014.

86. Yan, K.; Park, T.; Yan, G.; Liu, Z.; Yang, B.; Chen, C.; Nemani, R.R.; Knyazikhin, Y.; Myneni, B.R. Evaluation of MODIS LAI/fpar product collection 6. Part 2: Validation and intercomparison. Remote Sens. 2016, 8, 460. [CrossRef]

87. Camacho, F.; Cernicharo, J.; Lacaze, R.; Baret, F.; Weiss, M. Geov1: LAI, fapar essential climate variables and fcover global time series capitalizing over existing products. Part 2: Validation and intercomparison with reference products. Remote Sens. Environ. 2013, 137, 310-329. [CrossRef]

88. Lopresti, M.F.; Di Bella, C.M.; Degioanni, A.J. Relationship between MODIS-ndvi data and wheat yield: A case study in northern buenos aires province, Argentina. Inf. Process. Agric. 2015, 2, 73-84. [CrossRef]

89. Moriondo, M.; Maselli, F.; Bindi, M. A simple model of regional wheat yield based on NDVI data. Eur. J. Agron. 2007, 26, 266-274. [CrossRef]

90. Bolton, D.K.; Friedl, M.A. Forecasting crop yield using remotely sensed vegetation indices and crop phenology metrics. Agric. For. Meteorol. 2013, 173, 74-84. [CrossRef]

91. Labus, M.P.; Nielsen, G.A.; Lawrence, R.L.; Engel, R.; Long, D.S. Wheat yield estimates using multi-temporal NDVI satellite imagery. Int. J. Remote Sens. 2002, 23, 4169-4180. [CrossRef] 
92. Johnson, D.M. An assessment of pre- and within-season remotely sensed variables for forecasting corn and soybean yields in the united states. Remote Sens. Environ. 2014, 141, 116-128. [CrossRef]

93. Hamar, D.; Ferencz, C.; Lichtenberger, J.; Tarcsai, G.; Ferencz-ÁRkos, I. Yield estimation for corn and wheat in the hungarian great plain using Landsat mss data. Int. J. Remote Sens. 1996, 17, 1689-1699. [CrossRef]

94. Prasad, A.K.; Chai, L.; Singh, R.P.; Kafatos, M. Crop yield estimation model for iowa using remote sensing and surface parameters. Int. J. Appl. Earth Observ. Geoinf. 2006, 8, 26-33. [CrossRef]

95. Dominguez, J.A.; Kumhalova, J.; Novak, P. Winter oilseed rape and winter wheat growth prediction using remote sensing methods. Plant Soil Environ. 2015, 61, 410-416.

96. Julie, B.; Remy, F.; Frederic, B. Assimilation of LAI and dry biomass data from optical and SAR images into an agro-meteorological model to estimate soybean yield. IEEE J. Sel. Top. Appl. Earth Observ. Remote Sens. 2016, 9, 2540-2553.

97. Jin, X.; Li, Z.; Yang, G.; Yang, H.; Feng, H.; Xu, X.; Wang, J.; Li, X.; Luo, J. Winter wheat yield estimation based on multi-source medium resolution optical and radar imaging data and the aquacrop model using the particle swarm optimization algorithm. ISPRS J. Photogramm. Remote Sens. 2017, 126, 24-37. [CrossRef]

98. Liu, L.Y.; Wang, J.J.; Bao, Y.S.; Huang, W.J.; Ma, Z.H.; Zhao, C.J. Predicting winter wheat condition, grain yield and protein content using multi-temporal envisat-asar and Landsat TM satellite images. Int. J. Remote Sens. 2006, 27, 737-753. [CrossRef]

99. Maki, M.; Sekiguchi, K.; Homma, K.; Hirooka, Y.; Oki, K. Estimation of rice yield by simriw-rs, a model that integrates remote sensing data into a crop growth model. J. Agric. Meteorol. 2017, 73, 2-8. [CrossRef]

100. Delécolle, R.; Maas, S.J.; Guérif, M.; Baret, F. Remote sensing and crop production models: Present trends. ISPRS J. Photogramm. Remote Sens. 1992, 47, 145-161. [CrossRef]

101. Maas, S.J. Use of remotely-sensed information in agricultural crop growth models. Ecol. Model. 1988, 41, 247-268. [CrossRef]

102. Jiang, Z.; Chen, Z.; Chen, J.; Liu, J.; Ren, J.; Li, Z.; Sun, L.; Li, H. Application of crop model data assimilation with a particle filter for estimating regional winter wheat yields. IEEE J. Sel. Top. Appl. Earth Observ. Remote Sens. 2014, 7, 4422-4431. [CrossRef]

103. Chemin, Y.; Alexandridis, T. Water productivity at different geographical scales in zhanghe irrigation district, China. Int. J. Geoinf. 2006, 2, 9-19.

104. Alexandridis, T.K.; Gitas, I.Z.; Silleos, N.G. An estimation of the optimum temporal resolution for monitoring vegetation condition on a nationwide scale using MODIS/terra data. Int. J. Remote Sens. 2008, 29, 3589-3607. [CrossRef]

105. Alexandridis, T.K.; Katagis, T.; Gitas, I.Z.; Silleos, N.G.; Eskridge, K.M.; Gritzas, G. Investigation of aggregation effects in vegetation condition monitoring at a national scale. Int. J. Geogr. Inf. Sci. 2010, 24, 507-521. [CrossRef]

106. Kadhim, N.; Mourshed, M.; Bray, M. Advances in remote sensing applications for urban sustainability. Euro-Mediterr. J. Environ. Integr. 2016, 1, 7. [CrossRef]

107. Thorp, K.R.; Hunsaker, D.J.; French, A.N. Assimilating leaf area index estimates from remote sensing into the simulations of a cropping systems model. Trans. ASABE 2010, 53, 251-262. [CrossRef]

108. Seidl, M.S.; Batchelor, W.D.; Paz, J.O. Integrating remotely sensed images with a soybean model to improve spatial yield simulation. Trans. ASAE 2004, 47, 2081. [CrossRef]

109. Azzari, G.; Jain, M.; Lobell, D.B. Towards fine resolution global maps of crop yields: Testing multiple methods and satellites in three countries. Remote Sens. Environ. 2017, 202, 129-141. [CrossRef]

110. Basso, B.; Ritchie, J.T.; Pierce, F.J.; Braga, R.P.; Jones, J.W. Spatial validation of crop models for precision agriculture. Agric. Syst. 2001, 68, 97-112. [CrossRef]

111. Guo, C.; Zhang, L.; Zhou, X.; Zhu, Y.; Cao, W.; Qiu, X.; Cheng, T.; Tian, Y. Integrating remote sensing information with crop model to monitor wheat growth and yield based on simulation zone partitioning. Precis. Agric. 2018, 19, 55-78. [CrossRef]

112. Jin, X.; Kumar, L.; Li, Z.; Xu, X.; Yang, G.; Wang, J. Estimation of winter wheat biomass and yield by combining the aquacrop model and field hyperspectral data. Remote Sens. 2016, 8, 972. [CrossRef]

113. Rembold, F.; Atzberger, C.; Savin, I.; Rojas, O. Using low resolution satellite imagery for yield prediction and yield anomaly detection. Remote Sens. 2013, 5, 1704-1733. [CrossRef]

114. Clevers, J.G.P.W.; van Leeuwen, H.J.C. Combined use of optical and microwave remote sensing data for crop growth monitoring. Remote Sens. Environ. 1996, 56, 42-51. [CrossRef] 
115. Cooper, M.; Messina, C.D.; Podlich, D.; Totir, L.R.; Baumgarten, A.; Hausmann, N.J.; Wright, D.; Graham, G. Predicting the future of plant breeding: Complementing empirical evaluation with genetic prediction. Crop Pasture Sci. 2014, 65, 311-336. [CrossRef]

116. Frankenberg, C.; Berry, J.; Guanter, L.; Joiner, J. Remote sensing of terrestrial chlorophyll fluorescence from space. SPIE Newsroom 2013, 2-5. [CrossRef]

117. Young, A. (Ed.) Reducing the Cost to Low-Earth Orbit for Small Satellites bt-The Twenty-First Century Commercial Space Imperative; Springer International Publishing: Cham, The Netherlands, 2015; pp. 59-67.

118. Challinor, A.; Martre, P.; Asseng, S.; Thornton, P.; Ewert, F. Making the most of climate impacts ensembles. Nat. Clim. Chang. 2014, 4, 77. [CrossRef]

119. Ewert, F.; Rötter, R.P.; Bindi, M.; Webber, H.; Trnka, M.; Kersebaum, K.C.; Olesen, J.E.; van Ittersum, M.K.; Janssen, S.; Rivington, M.; et al. Crop modelling for integrated assessment of risk to food production from climate change. Environ. Model. Softw. 2015, 72, 287-303. [CrossRef]

120. Elliott, J.; Müller, C.; Deryng, D.; Chryssanthacopoulos, J.; Boote, K.J.; Büchner, M.; Foster, I.; Glotter, M.; Heinke, J.; Iizumi, T.; et al. The global gridded crop model intercomparison: Data and modeling protocols for phase 1 (v1.0). Geosci. Model Dev. 2015, 8, 261-277. [CrossRef]

121. Challinor, A.J.; Müller, C.; Asseng, S.; Deva, C.; Nicklin, K.J.; Wallach, D.; Vanuytrecht, E.; Whitfield, S.; Ramirez-Villegas, J.; Koehler, A.-K. Improving the use of crop models for risk assessment and climate change adaptation. Agric. Syst. 2017, 159, 296-306. [CrossRef] [PubMed]

122. Porter, J.R.; Liyong, X.; Challinor, A.; Cochrane, K.; Howden, M.; Iqbal, M.M.; Lobell, D.; Travasso, M.I. Chapter 7: Food security and food production systems. In Climate Change 2014: Impacts, Adaptation, and Vulnerability. Part A: Global and Sectoral Aspects. Contribution of Working Group II to the Fifth Assessment Report of the Intergovernmental Panel on Climate Chan; Cambridge University Press: Cambridge, UK, 2014.

123. Wollenberg, E.; Richards, M.; Smith, P.; Havlík, P.; Obersteiner, M.; Tubiello, F.N.; Herold, M.; Gerber, P.; Carter, S.; Reisinger, A.; et al. Reducing emissions from agriculture to meet the $2{ }^{\circ} \mathrm{C}$ target. Glob. Chang. Biol. 2016, 22, 3859-3864. [CrossRef] [PubMed]

124. Bajželj, B.; Richards, K.S.; Allwood, J.M.; Smith, P.; Dennis, J.S.; Curmi, E.; Gilligan, C.A. Importance of food-demand management for climate mitigation. Nat. Clim. Chang. 2014, 4, 924-929. [CrossRef]

125. Challinor, A.J.; Parkes, B.; Ramirez-Villegas, J. Crop yield response to climate change varies with cropping intensity. Glob. Chang. Biol. 2015, 21, 1679-1688. [CrossRef] [PubMed]

126. Bendig, J.; Yu, K.; Aasen, H.; Bolten, A.; Bennertz, S.; Broscheit, J.; Gnyp, M.L.; Bareth, G. Combining UAV-based plant height from crop surface models, visible, and near infrared vegetation indices for biomass monitoring in barley. Int. J. Appl. Earth Observ. Geoinf. 2015, 39, 79-87. [CrossRef]

127. Zhou, X.; Zheng, H.B.; Xu, X.Q.; He, J.Y.; Ge, X.K.; Yao, X.; Cheng, T.; Zhu, Y.; Cao, W.X.; Tian, Y.C. Predicting grain yield in rice using multi-temporal vegetation indices from UAV-based multispectral and digital imagery. ISPRS J. Photogram. Remote Sens. 2017, 130, 246-255. [CrossRef] 